\title{
Pengaruh Pelatihan Terhadap Pengetahuan tentang Gizi Buruk dan Inter-Professional Collaboration Petugas Puskesmas
}

\author{
Eny Pemilu Kusparlina \\ Fakultas Ilmu Formal dan Ilmu Terapan, Universitas Muhammadiyah Madiun; pemilu77@yahoo.co.id \\ (koresponden)
}

\begin{abstract}
The problem of nutritional status is very complex, requiring treatment involving a health nutritionist. The nutritional status of children is one of the important things to prepare a quality generation. Health education in the form of training is expected to be able to change the collaborative competences of health workers across professions. This study aims to analyze the effect of training on knowledge of health workers about malnutrition and cross-professional collaboration. The researcher used a mix-methods approach with triangulation techniques using a questionnaire for the qualitative stage by conducting content analysis, while in the quantitative stage the researcher used a pre-experimental design with a "one group pre and post test" design, then the data were analyzed using the Wilcoxon test and paired samples-t test. The results of the content analysis informed that the training had gone well and was able to increase the participants' knowledge. The statistical test results showed that the mean knowledge of nutrition before training was 4.50, while after training was 4.467. The results of the Wilcoxon test showed that the p value $=0.586$ (>0.05), so it can be interpreted that there is no difference in knowledge about nutrition between before and after training. Meanwhile, the average knowledge about collaboration before training was 8.75 and after training was 10.67. The results of the paired samples $t$-test showed a value of $p=0.008(<0.05)$, so it can be interpreted that there are differences in knowledge about collaboration before and after training. Furthermore, it was concluded that crossprofessional collaborative training on handling malnutrition had an effect on increasing the knowledge of health workers.
\end{abstract}

Keywords: malnutrition; training; knowledge; inter-professional collaboration

\begin{abstract}
ABSTRAK
Permasalahan status gizi yang sangat kompleks memerlukan penanganan yang melibatkan ahli gizi kesehatan. Status gizi anak menjadi salah satu hal penting untuk mempersiapkan generasi yang berkualitas. Pendidikan kesehatan dalam bentuk pelatihan diharapkan mampu mengubah kompetensi kolaborasi lintas profesi petugas kesehatan. Penelitian ini bertujuan untuk menganalisis pengaruh pelatihan terhadap pengetahuan petugas kesehatan tentang gizi buruk dan kolaborasi lintas profesi. Peneliti menggunakan pendekatan mix-methods dengan teknik triangulasi menggunakan kuesioner untuk tahapan kualitatif dengan melakukan analisis kontent, sedangkan pada tahapan kuantitatif peneliti menggunakan rancangan pra eksperimental dengan desain "one group pre and post test", lalu data dianalisis dengan Wilcoxon test dan paired samples- $t$ test. Hasil analisis konten menginformasikan bahwa pelatihan telah berlangsung dengan baik dan mampu meningkatkan pengetahuan peserta. Hasil uji statistik menunjukkan bahwa rerata pengetahuan tentang gizi sebelum pelatihan adalah 4,50, sedangkan setelah pelatihan adalah 4,467. Hasil paired samples-t test menunjukkan bahwa nilai $\mathrm{p}=$ 0,586 (>0,05), sehingga dapat diinterpretasikan bahwa tidak ada perbedaan pengetahuan tentang gizi antara sebelum dengan setelah pelatihan. Sedangkan rerata pengetahuan tentang kolaborasi sebelum pelatihan adalah 8,75 dan setelah pelatihan adalah 10,67 . Hasil Wilcoxon test menunjukkan nilai $\mathrm{p}=0,008(<0,05)$, sehingga dapat diinterpretasikan bahwa ada perbedaan pengetahuan tentang kolaborasi sebelum dan setelah pelatihan. Selanjutnya disimpulkan bahwa pelatihan kolaborasi lintas profesi pada penanganan gizi buruk berpengaruh terhadap peningkatan pengetahuan petugas kesehatan.
\end{abstract}

Kata kunci: gizi buruk; pelatihan; pengetahuan; inter-professional collaboration 


\section{PENDAHULUAN}

\section{Latar Belakang}

Kolaborasi adalah hubungan saling menguntungkan dan terdefinisi dengan baik yang disepakati oleh dua atau lebih organisasi untuk mencapai tujuan bersama. ${ }^{(1)}$ Hal ini merupakan istilah yang umum digunakan dalam penelitian, praktek klinis, dan pendidikan profesi kesehatan, hingga terjadi kolaborasi di hampir setiap aspek kesehatan. (2) Permasalahan pada bidang kesehatan yang sangat kompleks memerlukan penyelesaian secara bersama dengan melibatkan seluruh profesi kesehatan. ${ }^{(3)}$ Kerjasama dilakukan dengan upaya preventif dan promotif tanpa mengabaikan pendekatan kuratif dan rehabilitative. ${ }^{(4)}$

Kolaborasi inter-professional memiliki efek positif pada kepuasan pasien, mengurangi ketidakpastian, dan meningkatkan manajemen nyeri. Praktek kolaboratif inter-professional sangat penting untuk perbaikan hasil pelayanan kesehatan pada pasien / klien dan keluarga. World Health Organization (WHO) tahun 2010 menyatakan bahwa sekarang ini banyak sistem kesehatan di negara-negara di dunia yang mengimplementasikan pelayanan kesehatan terfragmentasi yang pada akhirnya tidak mampu menyelesaikan masalah kesehatan di negara itu sendiri.

Salah satu masalah kesehatan yang kompleks yakni status gizi buruk. Permasalahan yang ditimbulkan oleh status gizi buruk adalah kondisi yang tidak maksimal pada pertumbuhan dan perkembangan seorang anak. Sehingga upaya lain untuk mengatasi masalah gizi diperlukan aksi lintas sektoral. ${ }^{(5)}$ Secara global, $45 \%$ kematian anak dibawah usia 5 tahun diakibatkan oleh berbagai kondisi kekurangan gizi. ${ }^{(6)}$ Status gizi anak dapat diketahui dengan menggunakan pedoman penentuan status gizi yang tepat. ${ }^{(7)}$ Secara ilmiah ada hubungan antara mikronutrien dan pertumbuhan anak tetapi hal ini masih diperdebatkan. ${ }^{(8)}$

Pertumbuhan maksimal diderita sekitar 8 juta anak Indonesia, atau satu dari tiga anak Indonesia (Dasar RK, 2013). Pada tahun 2007 sampai 2011, proporsi penduduk miskin di Indonesia mengalami penurunan sebesar 16,6-12,5\%, tetapi masalah gizi tidak menunjukkan penurunan secara signifikan. Banyak faktor yang mempengaruhi status gizi anak salah satunya adalah pola pemberian ASI dan MP-ASI. ${ }^{(9)}$ Walaupun belum ditemukan korelasi antara kadar kalsium dalam ASI, PASI dan MPASI dalam intake bayi dengan panjang badan bayi usia 6-12 bulan. ${ }^{(10)}$ Pola asuh juga berhubungan dengan kejadian stunting pada anak usia 6-23 bulan di Makassar. ${ }^{(11)}$ Masih tingginya kejadian anemia defisiensi zat besi pada ibu hamil akan berfefek pada kondisi janin. ${ }^{(12)}$

Gambaran tentang status gizi balita berdasarkan indeks BB/U di atas target MDGs $(15,5 \%)$ menurut kota / kabupaten diperoleh informasi bahwa ada lima kabupaten dengan presentase tinggi gabungan gizi buruk dan gizi kurang yaitu Kabupaten Sumenep 31,7 \%, Kabupaten Bojonegoro 31 \%, Kabupaten Banyuwangi 29,6 \%, Kabupaten Ponorogo 29,6 \% dan Kota Madiun 28,4 \%.(13) Kabupaten Jeneponto memiliki status gizi buruk dan gizi kurang kategori masalah sedang sebesar 26,4\% sedangkan kasus gizi buruk sebanyak 7 orang $(0,04 \%){ }^{(14)}$

Berdasarkan latar belakang di atas, maka kerjasama lintas sektor menjadi salah satu kunci penting bagi suksesnya pembangunan kesehatan termasuk penanggulangan masalah gizi pada anak sehingga tulisan ini bertujuan untuk mengetahui pengaruh pelatihan terhadap pengetahuan tentang kolaborasi lintas profesi kesehatan pada penanganan kasus gizi buruk di Kota Madiun.

\section{METODE}

Jenis penelitian yang digunakan adalah deskriptif menggunakan mix methods (kualitatif dan kuantitatif). Penelitian ini bertujuan untuk menganalisis pengaruh pelatihan terhadap pengetahuan tentang kolaborasi lintas profesi kesehatan pada penanganan kasus gizi buruk. Penelitian ini dilaksanakan di Puskesmas Banjarejo Kota Madiun. Populasi dalam penelitian ini adalah semua petugas kesehatan yang bertugas di Puskesmas Banjarejo. Responden sebanyak 12 orang yang didapatkan dengan teknik stratified random sampling dan itu juga yang digunakan sebagai informan.

Pengumpulan data dilakukan dengan dua cara yaitu data primer melalui pengisian kuesioner, wawancara mendalam dengan informan dan observasi. Data sekunder berupa profil puskesmas, jumlah petugas kesehatan dan data-data lain yang diperlukan. Data yang telah dikumpulkan kemudian diuji normalitas data dan disajikan dalam bentuk tabel distribusi frekuensi. Selanjutnya karena data pengetahuan gizi buruk terdistribusi tidak normal maka dilakukan uji Wilcoxon dan pengetahuan tentang kolaborasi lintas profesi terdistribusi normal maka dilakukan paired samples t-test. Untuk data kualitatif, dianalisis menggunakan 
analisis konten dan matriks pernyataan informan dilakukan perbandingan dengan data kuantitatif yang telah diolah.

\section{HASIL}

\section{Karakteristik Responden}

Tabel 1. Distribusi karakteristik responden

\begin{tabular}{|c|c|c|}
\hline Karakteristik & Frekuensi & Persentase \\
\hline \multicolumn{3}{|l|}{ Jenis Kelamin } \\
\hline - Laki-laki & 3 & 25 \\
\hline - Perempuan & 9 & 75 \\
\hline \multicolumn{3}{|l|}{ Tingkat Pendidikan } \\
\hline - Strata I & 5 & 42 \\
\hline - Diploma & 7 & 58 \\
\hline \multicolumn{3}{|l|}{ Usia } \\
\hline - $20-30$ tahun & 5 & 41,2 \\
\hline - $\quad 31-40$ tahun & 5 & 41,2 \\
\hline - $\quad 41-50$ tahun & 2 & 16,6 \\
\hline \multicolumn{3}{|l|}{ Profesi } \\
\hline - Dokter & 2 & 16,6 \\
\hline - $\quad$ Perawat & 2 & 16,6 \\
\hline - Bidan & 3 & 25 \\
\hline - Nutrisionis & 2 & 16,6 \\
\hline - Sanitarian & 2 & 16,6 \\
\hline - $\quad$ Promosi kesehatan & 1 & 8,3 \\
\hline
\end{tabular}

Tabel 1 memperlihatkan bahwa mayoritas informan berjenis kelamin perempuan. Tingkat pendidikan mayoritas informan adalah diploma. Kelompok usia informan terbanyak adalah 20-30 tahun dan 31-40 tahun. Selain itu profesi yang dimiliki informan bervariasi dan paling banyak adalah bidan.

\section{Pengetahuan Responden}

Pada penelitian ini mengukur pengetahuan subyek maka peneliti memberikan pre-test sebelum kegiatan pelatihan dan di berikan modul saat kegiatan pelatihan berlangsung. Setelah kegiatan pelatihan maka dilakukan kembali post-test.

Tabel 2. Perubahan pengetahuan responden antara sebelum dan sesudah pelatihan di Kota Madiun tahun 2018

\begin{tabular}{|c|c|c|r|r|c|}
\hline \multirow{2}{*}{ Pengetahuan } & \multicolumn{2}{|c|}{ Pre } & \multicolumn{2}{|c|}{ Post } & \multirow{2}{*}{ p-value } \\
\cline { 2 - 5 } & Mean & SD & Mean & SD & \\
\hline Gizi buruk & $\cdot 4,50$ & 0,674 & 4,67 & 0,492 & $0,586^{*}$ \\
\hline Kolaborasi & 8,75 & 0,965 & 10,67 & 1,670 & $0,008^{* *}$ \\
\hline
\end{tabular}


Tabel 2 menunjukkan bahwa untuk pengetahuan tentang gizi sebelum pelatihan memiliki rerata 4,50 dan setelah pelatihan memiliki rerata 4,467 . Hal ini tidak menunjukkan peningkatan rerata. Hasil uji statistik yakni paired samples $t$-test menunjukkan nilai $\mathrm{p}=0,586(>0,05)$ yang bermakna bahwa tidak ada perbedaan rerata pengetahuan tentang gizi sebelum dengan setelah pelatihan.

Sedangkan untuk pengetahuan tentang kolaborasi sebelum pelatihan memiliki rerata 8,75 dan setelah pelatihan memiliki rerata 10,67 . Hal ini menunjukkan adanya peningkatan rerata. Hasil Wilcoxon test menunjukkan nilai $\mathrm{p}=0,008(<0,05)$ yang menunjukkan ada perbedaan rerata pengetahuan tentang kolaborasi sebelum dengan setelah perlakuan pada kelompok uji coba modul.

Dalam mendukung penelitian ini secara kualitatif, maka dilakukan indepth interview pasca pelatihan. Secara umum diperoleh informasi baru dan terjadi perubahan pengetahuan peserta tentang gizi buruk dan kolaborasi setelah mengikuti pelatihan sebagaimana sesuai kutipan berikut:

1. “....Bagus, penjelasannya sangat terarah. Mendapat pelajaran yang sangat berarti. (SR.Perawat)

2. “....Terima kasih, sudah melakukan pelatihan ini di tempat kami sehingga kami dapat ilmu baru (SA.Bidan)

3. “...... Saya sangat berterima kasih ada ibu untuk memberikan pelatihan ini karena menambah ilmu bagi saya (NI. Ahli gizi)

4. “....... Saya sangat berterima kasih dengan kehadiran yang telah menambah pengetahuan kami tentang pentingnya kolaborasi dalam semua kegiatan utamanya program kami (EE.Sanitarian)\|

Evaluasi tentang proses pelatihan yang telah berlangsung secara lancar dan ternilai bagus oleh peserta. Sebagaimana beberapa kutipan pernyataan sebagai berikut;

1. -...Tema pelatihan sangat kreatif, inovasi dan bermanfaat. Penyajian materi dikemas sangat menarik sehingga tidak membosankan. Servis mantap. Narasumber ramah dan selalu memberi kesempatan peserta untuk memberi umpan balik."(AD, Dokter)

2. - -...Pembawaan materinya sangat bagus dan mudah dipahami. Berkolaborasi dengan pesertanya dengan mudah.\| (KS, Tenaga Promkes)

\section{PEMBAHASAN}

Dalam penelitian ini, diperoleh bahwa setelah kegiatan uji coba modul maka pengetahuan tentang gizi buruk setelah dilakukan uji statistik yakni uji Wilcoxon memperoleh nilai 0,586 bermakna bahwa tidak ada perbedaan rerata pengetahuan tentang gizi sebelum dengan setelah perlakuan namun pengetahuan tentang kolaborasi lintas profesi setelah dilakukan uji $\mathrm{T}$ test memperoleh nilai 0,008 menunjukkan ada perbedaan rerata pengetahuan tentang kolaborasi sebelum dengan setelah perlakuan pada kelompok uji coba modul.

Pemahaman yang baik tentang kolaborasi lintas profesi telah dimiliki oleh petugas kesehatan. Kolaborasi adalah istilah yang umum digunakan dalam penelitian, praktek klinis, dan pendidikan profesi kesehatan. ${ }^{(15)}$ Bekerja dengan cara yang inter-professional bukanlah konsep baru. Pada literatur profesional, terutama dalam ilmu kesehatan jelas bahwa sangat banyak manfaat dan tantangan untuk mengintegrasikan tenaga kerja untuk belajar dan menghargai budaya profesi lainnya. Keterampilan ini dapat dialihkan untuk banyak daerah di mana orang bekerja sama dengan profesi lain untuk mencapai tujuan bersama. ${ }^{(16)}$

Upaya meningkatkan kolaborasi di pelayanan kesehatan dapat dilakukan dengan berbagai cara dalam pendidikan kesehatan. Salah satu strategi yang dipergunakan berupa kegiatan pelatihan. Banyak pelatihan yang telah dilaksanakan dan berpengaruh pada pengetahuan dari peserta kegiatan tersebut. Diantaranya adalah program pelatihan pemeriksaan payudara sendiri yang memberikan perubahan pengetahuan pesertanya setelah mengikuti pelatihan tersebut. ${ }^{(17)}$

Walaupun ada juga pelatihan yang tidak mampu mengubah pengetahuan peserta pelatihan setelah dilakukan uji pre dan post intervensi. ${ }^{(18)}$ Namun dipahami bahwa Pengetahuan, keterampilan dan motivasi mempunyai hubungan dengan kinerja bidan. Karena factor social dan psikologis berhubungan dengan pelayanan kesehatan. Sehingga upaya penanganan kasus gizi buruk memerlukan kemampuan kolaborasi lintas profesi kesehatan dalam sebuah sistem pelayanan kesehatan. ${ }^{(19)}$

Selain itu keberadaan kader juga perlu diperhatikan dalam pelayanan kesehatan karena keberadaan kader yang mempunyai pengetahuan dan keterampilan untuk menyampaikan informasi dan motivasi kepada wanita prakonsepsi dalam mendapatkan akses pelayanan kesehatan. Pendidikan kesehatan merupakan salah satu upaya dalam penambahan pengetahuan dan kemampuan seseorang dengan tujuan untuk mengingat fakta atau kondisi 
nyata. Dengan cara memberi dorongan terhadap pengarahan diri serta aktif dalam memberikan informasi atau ide baru. ${ }^{(20)}$

Konsep pendidikan kesehatan adalah konsep pendidikan yang diaplikasikan pada bidang kesehatan. Konsep dasar pendidikan adalah suatu proses belajar yang berarti dalam pendidikan itu terjadi proses pertumbuhan, perkembangan, atau perubahan kearah yang lebih dewasa, lebih baik, lebih matang pada diri individu, kelompok / masyarakat. Konsep pendidikan kesehatan itu juga proses belajar pada individu, kelompok atau masyarakat dari tidak tahu tentang nilai-nilai kesehatan menjadi tahu, dari tidak mampu mengatasi masalah kesehatan menjadi mampu mengatasi masalah kesehatan.

Pendidikan kesehatan adalah penambahan pengetahuan dan kemampuan seseorang melalui teknik praktik belajar atau instruksi, dengan tujuan untuk mengingat fakta atau kondisi nyata, dengan cara memberi dorongan terhadap pengarahan diri (self direction), aktif memberikan informasi atau ide baru. Pendidikan kesehatan adalah proses perubahan perilaku yang dinamis bukan proses pemindahan materi dari seseorang ke orang lain dan bukan pula seperangkat prosedur. ${ }^{(21)}$

Hal itu dapat dilihat dari definisi yang dikemukakan yaitu pendidikan kesehatan adalah suatu proses perubahan pada diri seseorang yang dihubungkan dengan pencapaian tujuan kesehatan individu, dan masyarakat. Dari definisi tersebut menunjukkan bahwa pendidikan kesehatan merupakan suatu proses perubahan perilaku yang dinamis dengan tujuan mengubah atau memengaruhi perilaku manusia yang meliputi komponen pengetahuan, sikap, ataupun praktik yang berhubungan dengan tujuan hidup sehat baik secara individu, kelompok maupun masyarakat, serta merupakan komponen dari program kesehatan. ${ }^{(22)}$

Sesuatu yang dipelajari akan membentuk pengetahuan, seringkali pengetahuan tersebut terlupakan. Ada beberapa sebab seseorang yang telah memperoleh pengalaman tetapi sulit diingat, Seseorang cenderung lupa karena tergantung pada sesuatu yang diamati, situasi dan proses pengamatan berlangsung serta waktu. ${ }^{(23)}$ David Kolb yang dikutip Depkes RI menyatakan bahwa pengetahuan sebagai hasil dari proses belajar sangat dipengaruhi oleh waktu sejak memperoleh pemaparan.

Ada beberapa faktor yang memengaruhi pengetahuan seseorang yakni

1) Tingkat pendidikan, Sebagaimana kita pahami bahwa semakin tinggi tingkat pendidikan seseorang, maka yang bersangkutan akan lebih mudah dalam proses menerima hal-hal baru sehingga pada akhirnya akan lebih mudah pula menyelesaikan persoalan terkait dengan hal-hal baru tersebut.

2) Informasi, Bila seseorang mempunyai sumber informasi yang lebih baik, akurat dan banyak maka akan memberikan pengetahuan yang jelas berdasarkan pada sumber informasi tersebut.

3) Budaya dapat dipahami memberikan efek yang sangat mempengaruhi tingkat pengetahuan seseorang, karena berbagai informasi baru yang masuk akan disaring oleh individu untuk memilah kira-kira informasi tersebut sesuai atau tidak dengan kebudayaan yang telah ada dan agama yang dianut masyarakat.

4) Pengalaman, sangat berkaitan dengan jumlah umur dan pendidikan indivdu, artinya, pendidikan yang tinggi disertai dengan pengalaman hidup yang luas seiring dengan umur yang bertambah tua.

5) Sosial Ekonomi, dimaknai bahwa tingkatan seseorang untuk memenuhi kebutuhan hidup akan disesuaikan dengan jumlah penghasilan yang ada, sehingga mengharapkan pengetahuan yang dimiliki harus dipergunakan semaksimal mungkin, hal ini sesuai pula dalam mencari bantuan ke fasilitas pelayanan kesehatan yang ada, maka akan disesuaikan dengan pendapatan keluarga. Faktor lain yang juga mendukung adalah informasi.

Hasil penelitian didukung oleh teori yang dikemukakan oleh Atkinson dan Shiifrin dalam Satrock menyatakan bahwa semakin lama informasi dipertahankan dalam memori jangka pendek dengan bantuan pengulangan, semakin besar kemungkinannya untuk masuk ke memori jangka panjang, sehingga relative menjadi lebih permanen. Pengetahuan akan disimpan lama dalam memori jika dilakukan pengulangan dengan mengingat kembali pada saat dibutuhkan.

Pendidikan kesehatan sangat penting untuk menunjang program-program kesehatan yang lain. Pendidikan merupakan „behavioral investment" jangka panjang. artinya pendidikan kesehatan baru dapat dilihat beberapa tahun kemudian. Dalam waktu yang pendek (immediate impact) pendidikan kesehatan hanya menghasilkan perubahan atau peningkatan pengetahuan masyarakat. Pengetahuan kesehatan akan berpengaruh pada perilaku sebagai hasil jangka menengah (intermediate impact) dari pendidikan kesehatan.

Selanjutnya akan berpengaruh pada peningkatan indikator kesehatan masyarakat sebagai keluaran (outcome) pendidikan kesehatan. Pendidikan kesehatan bukan hanya pelajaran di kelas, tetapi merupakan kumpulan pengalaman dimana saja dan kapan saja sepanjang klien dapat memengaruhi pengetahuan sikap dan kebiasaan. Terdapat pula hubungan antara pengetahuan, pelatihan dan ketersediaan sarana. ${ }^{(24)}$ Sehingga kegiatan pelatihan sebagai salah satu upaya peningkatan kualitas pelayanan kesehatan sangat diperlukan. 
Penelitian ini masih mempunyai berbagai keterbatasan yakni jumlah informan yang juga sebagai responden belum mewakili seluruh profesi yang bekerja di Puskesmas lokasi penelitian, sehingga hasilnya belum mampu direpresentasikan sebagai hasil pada tingkat Puskesmas di Kota Madiun.

\section{KESIMPULAN}

Pelaksanaan pelatihan kolaborasi lintas profesi telah terlaksana dengan proses yang baik. Walaupun pada akhir kegiatan uji coba modul diperoleh hasil bahwa pada kegiatan uji coba modul dalam kegiatan pelatihan tersebut menunjukkan bahwa tidak terjadi perubahan pengetahuan tentang gizi buruk namun terjadi perubahan pengetahuan tentang kolaborasi lintas profesi sebagai bagian utama dari modul.

\section{DAFTAR PUSTAKA}

1. Posthumus et al. Bridging between Professionals in Perinatal Care: towards Shared Care in the Netherlands. Maternal and Child Health Journal. 2018;17(10):1981-1989.

2. Green BN, Johnson CD. Inter-Professional Collaboration in Research, Education, and Clinical Practice: Working Together for a Better Future. Journal of Chiropractic Education. 2015;29(1):1-10.

3. Kementerian Kesehatan RI. Rencana Strategis Kementerian Kesehatan tahun 2015-2019. Jakarta: Kemenkes RI; 2015.

4. Sumarni S. Peran Sarjana Kesehatan Masyarakat dalam Gerakan Penyelamatan 1000 HPK untuk Menurunkan Stunting dan Angka Kematian Ibu. Seminar \& Saresehan Nasional Kesehatan Masyarakat. 2015:20-30.

5. UNICEF. Ringkasan Kajian Kesehatan Ibu dan Anak. Jakarta: UNICEF; 2012.

6. Black et al. Maternal and Child Undernutrition and Overweight in Low-Income and Middle-Income Countries. The Lancet. 2013;382(9890):427-451.

7. Alfridsyah A, Ichsan I, Miko A. Perbedaan Penggunaan Standar Baru Antropometri WHO-2006 terhadap Peningkatan Pengetahuan dan Penilaian Status Gizi pada Tenaga Gizi Pelaksana di Kota Banda Aceh Tahun 2009. Buletin Penelitian Sistem Kesehatan. 2013;16(2 Apr).

8. Syam, et al. Micronutrients and growth of children; a literature review. International Journal of Medical Science and Public Health. 2016;5(10):1981-1987.

9. Susanty, et al. Hubungan Pola Pemberian ASI dan MP-ASI dengan Gizi Buruk pada Anak 6-24 Bulan di Kelurahan Pannampu Makassar. Media Gizi Masyarakat Indonesia. 2012;1(2);97-103.

10. Febria C, Masrul M, Chundrayetti E. Hubungan Kadar Kalsium Dalam ASI, PASI dan MPASI dari Asupan Bayi dengan Panjang Badan Bayi Usia 6-12 Bulan di Wilayah Kerja Puskesmas Lubuk Buaya Padang 2017. Jurnal Kesehatan Andalas. 2018;6(3):662-667.

11. Renyoet BS, Hadju V, Rochimiwati S. Hubungan Pola Asuh dengan Kejadian Stunting Anak Usia 6-23 Bulan di Wilayah Pesisir Kecamatan Tallo Kota Makassar. Jurnal Nutrient Science (PA-NSC). 2012:1-13.

12. Amiruddin R. Anemia Defisiensi Zat Besi pada Ibu Hamil di Indonesia. Jurnal Medika Unhas. 2007.

13. Kemenkes RI. Riset Kesehatan Dasar 2013. Jakarta: Badan Penelitian dan Pengembangan Kesehatan, Kementerian Republik Indonesia; 2013.

14. Dinkes Kota Madiun. Laporan Pelaksanaan Surveilans Gizi tingkat Kota Madiun. Madiun: Dinkes Kota Madiun; 2018.

15. Green BN, Johnson CD. Inter-Professional Collaboration in Research, Education, and Clinical Practice: Working Together for a Better Future. Journal of Chiropractic Education. 2015;29(1):1-10.

16. Borst J. Inter-professional Collaboration: An Introduction. Tartalom. 2011;32.

17. Seif NY, Aziz MA. Effect of Breast Self-Examination Training Program on Knowledge, Attitude and Practice of a Group of Working Women. J Egypt Natl Canc Inst. 2000;12(2):105-115.

18. Ellis et al. Effect of Pharmacy Practice Residency Training on Residents' Knowledge of and Interest in Clinical Research. American Journal of Health-System Pharmacy. 2007;64(19).

19. Saleh PA, Amir MY, Palutturi S. Hubungan Faktor Sosial dan Psikologis dengan Pemanfaatan Pelayanan Kesehatan di RS Bhayangkara Makassar. Jurnal Penelitian Administrasi dan Kebijakan Kesehatan FKM Universitas Hasanuddin. 2012

20. Paridah CA, Thaha R. The Role of the Center for Prenatal and Postnatal Health Care and Information Cadres in Integrated Care for Preconception Womenin the Pattingalloang Community Health Center Area. JURNAL MKMI. 2014;102-109.

21. Suliha U. Pendidikan Kesehatan dalam Keperawatan. Jakarta: Penerbit Buku Kedokteran EGC; 2012.

22. Notoatmodjo S. Pendidikan dan Perilaku Kesehatan. Jakarta: Rineka Cipta; 2007. 
23. Purwanto MN. Psikologi pendidikan. Bandung: Remaja Rosdakarya; 2010.

24. Sujianto U. Kepatuhan Perawat dalam Penerapan Kewaspadaan Universal di Rumah Sakit dr. Kariadi Semarang Tahun 2013. Prosising Seminar Nasional. 2014. 